\title{
MEGALITHS, TYPES, AND ITS LIVING TRADITIONS AMONG THE JAINTIAS OF NORTHEASTERN INDIA
}

\author{
Queenbala Marak \\ Assistant Professor,Department of Anthropology,North-Eastern Hill University,Shillong-793022, Meghalaya, India.Email: \\ qmarak@gmail.com
}

\begin{abstract}
The Jaintias of India are a group of people who are even today known to use megaliths in their regular and ceremonial lives. One of the oldest villages with such traditions is a village named Nangbah in Jaintia Hills District in the state of Meghalaya. The present paper is an outcome of a study done on the megalithic remains in Nangbah village and its associated cultural practices in December-January 2010. Interestingly the megaliths number over five hundred, and can be classified into different types based on morphology and function. More interesting is the cultural meanings involved therein. These structures are not only an indication of living practices such as veneration of the dead, and abode of the village gods and goddesses, but also reiterates the social structure of their society - that of matriliny.
\end{abstract}

\section{INTRODUCTION}

Megaliths are a common feature in different parts of the world, including India. Such structures are generally attested to prehistoric times. The meanings are varied, and studies have provided diverse insights into socio-political, economic and ideological life of prehistoric societies. Majority of these studies are concerned with how they played an important role in the beginnings of early agricultural communities, and creation of complex polities (Renfrew 1976). Chapman (1981) discusses how megalithic monuments in Neolithic Europe acted as territorial markers which were in turn controlled by kinship-based corporate groups. They were also seen as representations of an elite class of individuals and groups (Flemming 1973, Sherrat 1990, Nelson 1999). A few studies focused on the symbolism inherent in them (Hodder 1990, Thomas 1993, Bradley 1998, Tilley 2004). Bradley (1998), for instance, discussed early megalith construction in Europe in terms of an emerging belief system which emphasized the power of humans and their domestication of the natural world, an idea that was in opposition to the earlier inseparable and symbiotic ties between the natural and human world. A few other studies (Thom 1966, MacKie
1997) contended that megaliths were monuments used for astronomical observations.

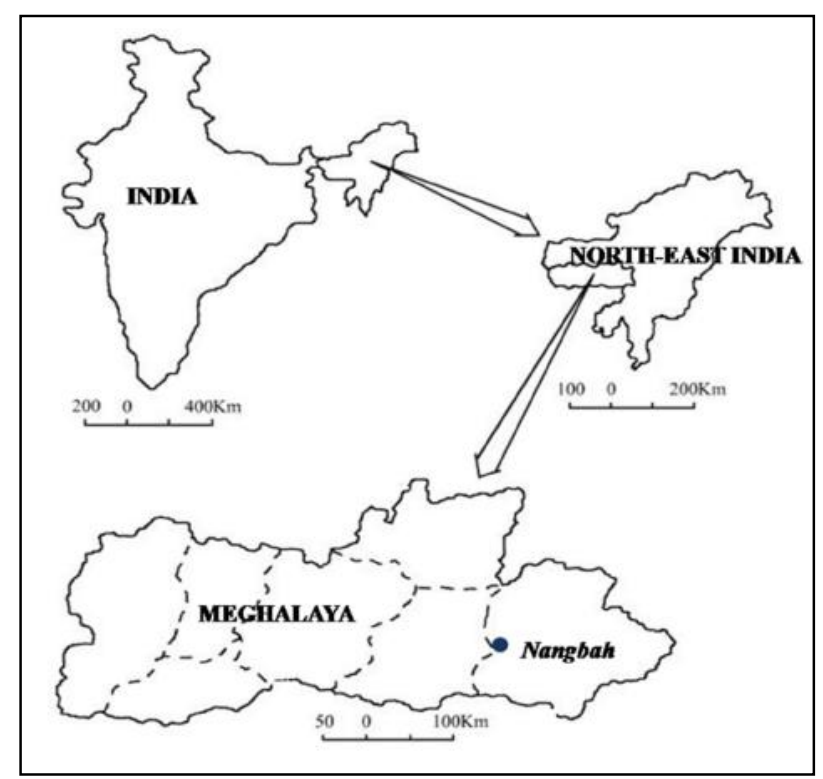

Figure 1: Map of India showing the location of Nangbah

In India, however, despite the meanings inherent in them, two independent traditions are seen. One, which is clearly of prehistoric context as found in south India characterised by iron and black-and-red pottery occurring in direct association and hence datable to the Iron Age (1000BC-1000AD). The second, found in eastern and central India, shows a living tradition with strong cultural connotations. These two groups clearly had no connection at all (Furer-Haimendorf 1945, Ramachandran 1971). These megaliths in eastern and central India shows morphological and functional variations, as well as diversity of beliefs in contemporary megalithic cultures. Therefore it is difficult to categorise them. In northeastern India, where the present study was undertaken, megaliths are found widely distributed in the Khasi-Jaintia Hills of 
Meghalaya (Godwin-Austen 1872, Gurdon 1914), in Naga dominated areas of the districts of Chandel, Ukhrul, Tamenglong, Senapati and Churachandpur in Manipur (Singh 1985, Devi 2011), in North Cachar Hills and Karbi Anglong districts of Assam (Mills and Hutton 1929, Bezbaruah 2004), and in Kohima and Phek districts of Nagaland populated by Angamis and others (Dewar 1966, Jamir 1998). In these areas there exists a living tradition among the tribal communities of erection of megalithic monuments and linked beliefs - this cultural practice associated with the megaliths among living communities is referred to as living megalithism (Marak and Jangkhomang 2012b).

Megaliths in northeast India have different meanings to different people. For instance, among the Nagas living in neighbouring states of Manipur and Nagaland, erection of megaliths takes place after a series of feasts of merit by the merit seeker (Dewar 1966, Singh 1985, Jamir 1998, Devi 2011). Thus they act as a symbol of status. Among the Garos of Meghalaya, whenever a new village is set up, the clan members of the founding mother erect a set of menhirs (Marak 2012), thus acting as foundation stones. Among the Jaintias too there are different meanings inherent in these lithics. However a few of these structures have now been relegated to the background after the coming of Christianity (Marak and Jangkhomang 2012b). The study of this culture among the Jaintias gains importance since they are a matrilineal group with megaliths dominating their geo-cultural space. This paper therefore tries to look into the megalithic types, traditions, and its cultural meanings among the Jaintias of the state of Meghalaya in the Indian Union. The discussions follow the anthropological empirical traditions of village ethnography. In this context, Nangbah, one of the oldest Jaintia villages situated in Jaintia Hills District, Meghalaya state, has been studied. This is an exploratory study with a one-month fieldwork in January 2010, followed by two follow-up field visits, when both ethnographic and ethnoarchaeological data was collected and analysed. This village is situated to the northeast of Jowai town, the capital of the district, on the JNKK (Jowai-NartiangKhiap-Khanduli) road about $13 \mathrm{kms}$ from the capital towards Khanduli (Figure 1).

\section{A VILLAGE OF STONES AND GROVES}

The village of Nangbah is populated by the Jaintias, a sub-tribe of the greater Khasi group, who prefer to call themselves Pnar and follow matriliny. However the present village stands out from other villages due to its proliferation of megaliths and sacred groves. A number of sacred groves are present in the village with different spatial dimensions. Some of these groves are as large as $100 \mathrm{~m}^{2}$ while others are as small as a patch of land where one tree stands. There are 20 such groves in Nangbah which can be categorized as "sacred" due to its sacrosanct nature (Marak and Ghimire 2012).

Among these, Khloo Lyngdoh and Ringein are the biggest in size while Kyndong Syiem is the smallest where only one tree remains. Iawmusiang is one of the important sacred groves where a large number of megaliths are present. Moomala is a grove where human settlement has taken place, and the sacred area comprises of only one tree and a small space for rituals. The rest of the groves are small patches of forest land having some megalithic structures and accompanying religious significance. The importance of the groves comes in since the Jaintias have a number of ritualistic activities surrounding the megaliths in these groves.

Nangbah has a population of 4279 individuals, half of whom are followers of Niamtre, and the rest converts to Christianity. Niamtre is the traditional Jaintia religion which believes in ancestor and spirit worship, with accompanying beliefs and practices. Interestingly, female deities are seen to be agents of familial, social well-being and collective economic endeavours, whereas male deities are connected to state activities, administration and territorial defence (Sen 2004). Jaintia matriliny has been much studied and debated for its "unique" system of marriage, popularly referred by anthropologists as "visiting husband marriage". This is so called because among them unlike other systems of matriliny, post-marital residence is partial: in this system even though the husband moves into the house of the wife, for all practical purposes including economic ventures, he is an important member of his mother's house. He continues earning for his mother's house despite being married - this situation, however, has changed to some extent in the present times. As in other systems of matriliny, inheritance of property, lineage, and residence after marriage is in the female line. The men live and work with their mother and her clan and their right of ownership exists in the mother's clan alone, where they occupy an important position. In such a matrilineal system, the inheriting daughter is the youngest ( $k$ hadduh), who assumes the role of the custodian of family property and the responsibilities towards aged parents, maternal uncles, brothers, sisters and their children.

Besides the family (iing), which is the smallest and most important social unit, the clan $(k u r)$ is of great importance; some families are grouped into lineages ( $\mathrm{kpoh})$ or sub-clans, which are further grouped into the larger clan. All clans trace their origin from a common ancestress and their descent is from mother to daughter; sons trace their descent from the mother as well. In the village there are twenty clans out of which it is likely that originally there were only twelve clans since only these are represented in the form of clan stones in the sacred grove of Iawmusiang. These twelve clans are the Pasi, Dhar, Biam, Hinge, Thubru, Susngi, Pale, Kawah, Kahit, Maskut, Lakadong and Lajied. It is also said that if any of these 
twelve clans are found in other villages, they invariably trace their origin to Nangbah, thereby demonstrating that it is possibly one of the oldest villages in Jaintia Hills.

Thus the megaliths of Iawmusiang interestingly represent twelve clans of the village, and these are said to have been erected by ancestors during different periods of time. In the centre of these twelve clan stones lie a dolmen called sangap. The goddess of Iawmusiang is believed to reside here. As the legend goes Sangap, who hailed from the village had a wife at Shangpung and according to their visiting husband marriage system, he would visit his wife at night and leave early in the morning. Once when there were torrential rains, he asked his wife for a knup (rain shield made of bamboo and cane) but his wife jokingly told him to use a stone as cover. Sangap searched long and hard for a large, flat stone in the pelting rain and on finding one used it as a rain shield and carried it all the way to Nangbah. This stone was laid in the centre of the village and became the abode of the goddess of Iawmusiang (Figure 2).

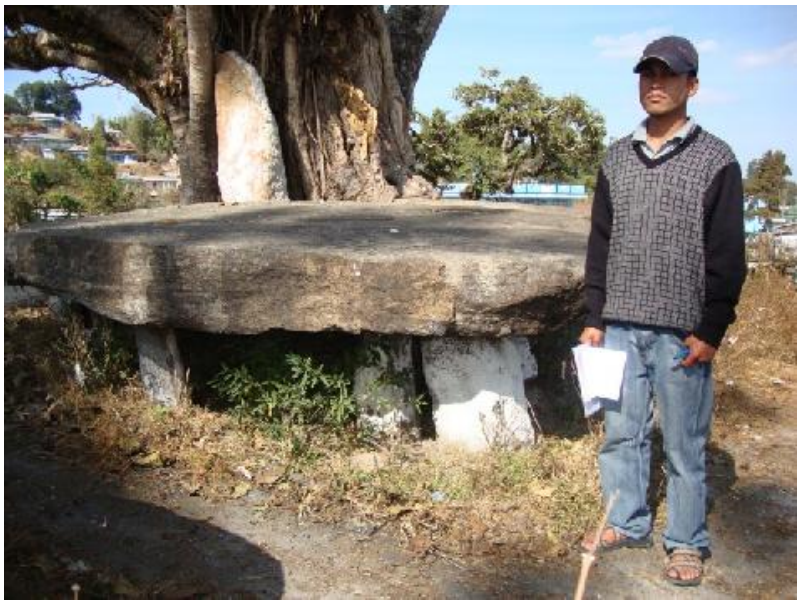

Figure 2: The stone of Sangap where the goddess of Iawmusiang resides

\section{MEGALITHS OF NANGBAH}

The megaliths in Nangbah total over five hundred in number. In the following pages, an attempt is made to classify the megaliths found in Nangbah by morphological and functional characteristics.

\section{A. Morphological Types}

\section{Menhirs}

These upright standing structures are common. The local term for such upright standing stones is moopynieng (moo=stone, pynieng=standing) or mooshyarang ( $m o o=$ stone, shyarang=male). The menhirs in Nangbah are mostly found in association with dolmens, and they vary from $30-550 \mathrm{cms}$ in height. Some of the notable menhirs found in the village include $u$-moothulelane (stone of thule lane), the tallest menhir found in Nangbah, at a height of $563 \mathrm{cms}$ (Figure 3); and moopyllaitsyier (stone where the cock is set free) at a height of $192 \mathrm{cms}$ located at Khlopano locality.

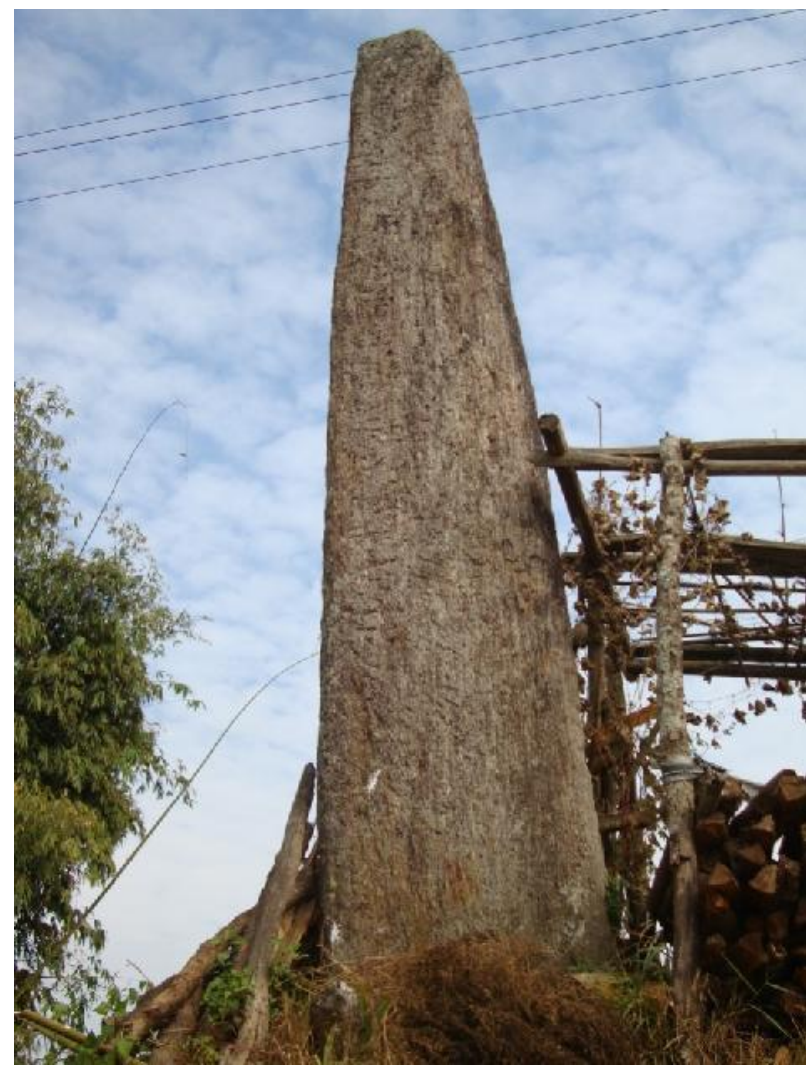

Figure 3: U-moothulelane, in memory of the victory over the "giant' of Nongjingi

\section{Alignments}

In Nangbah alignments are found in plenty. One of the alignments is a group of 15 menhirs in a straight line. These are the clan stones of the Susngi clan comprising of menhirs in association with dolmens and stone slabs or capstones. The menhirs vary in height from $30-213 \mathrm{cms}$ Other menhirs measuring $60-152 \mathrm{cms}$ in height are also found in a straight line in Iawmusiang marking the boundary of the area, while still others are found leading to clan cists (Figures 4 and 5).

\section{Stone Circles}

The stone circle found in Iawmusiang comprises of menhirs in association with dolmens and stone slabs or capstones. It includes circular arrangement of 9 menhirs in association with 11 dolmens and 2 stone slabs. 


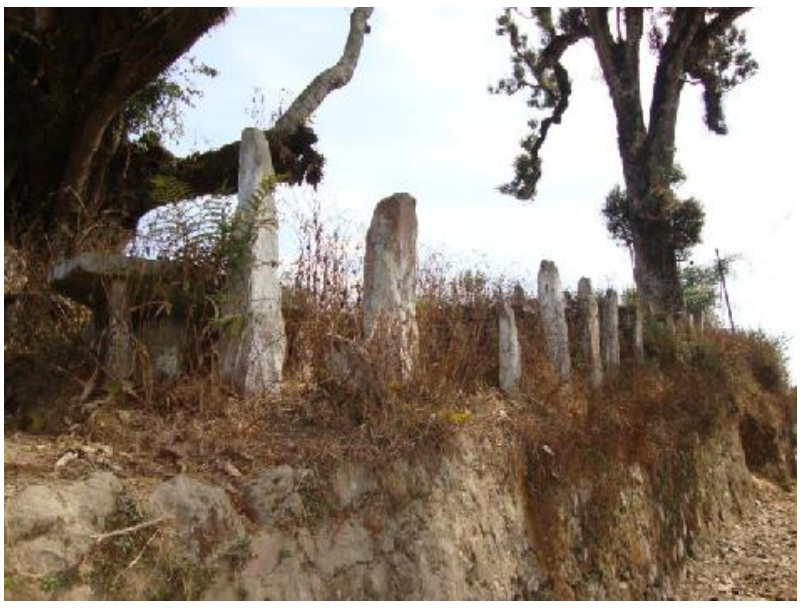

Figure 4: An alignment marking out the boundary

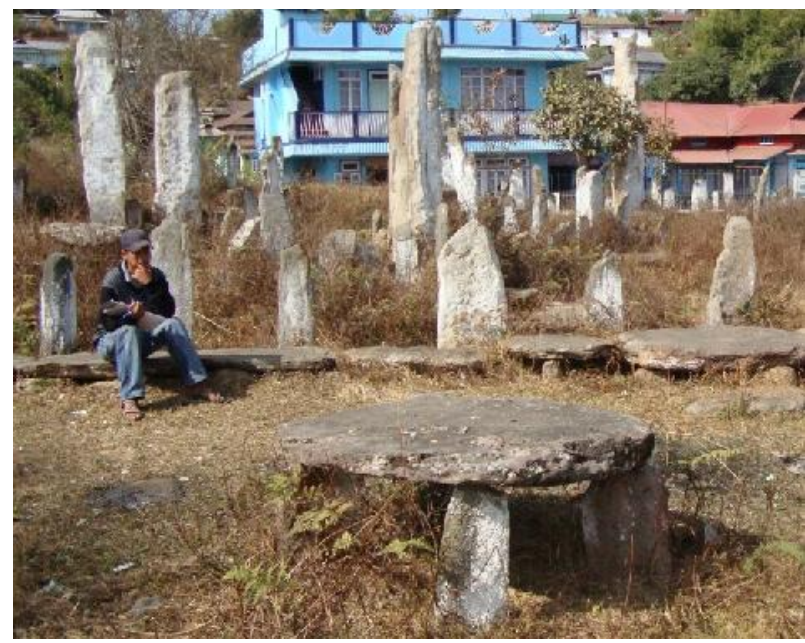

Figure 5: A group of clan stones in alignment in the sacred grove of Iawmusiang

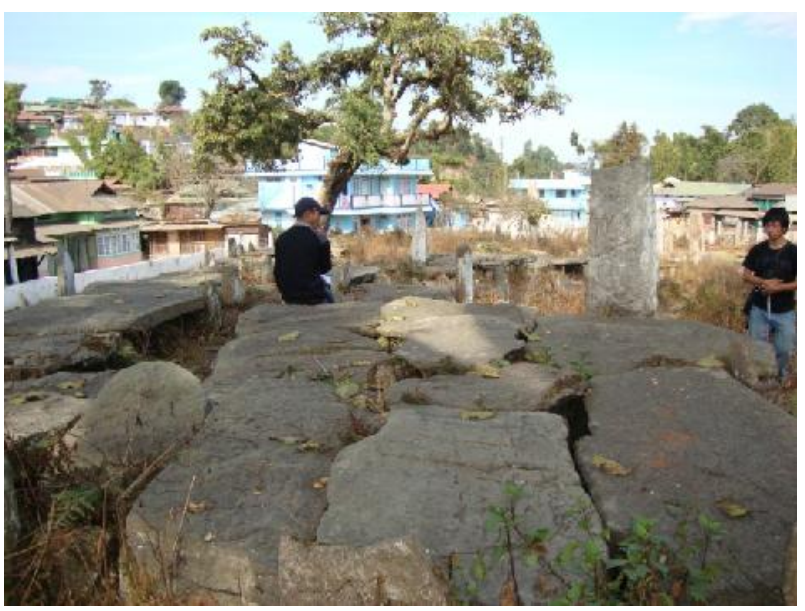

Figure 6: Stones for seating and resting

\section{Dolmens}

Dolmens are known as mooknor ( $m o o^{=}$stone, $k n o r=$ flat)or mookynthai (moo=stone, kynthai=female). They are usually found singly or in a group in association with menhirs. The dolmens found are $91-152 \mathrm{cms}$ in length and 60 $152 \mathrm{cms}$ in breadth and $20-30 \mathrm{cms}$ thick with about 10 $20 \mathrm{cms}$ from the ground. One of the notable dolmens is blaiiawmusiang (stone where the goddess of Iawmusiang resides), also called sangap the first megalith placed in Iawmusiang. This measures $351 \times 232 \times 27 \mathrm{cms}$ at a height of $20 \mathrm{cms}$. Moolyngdoh (lyngdoh stone) is another important dolmen, located in the same grove opposite sangap, measuring $137 \times 161 \times 20 \mathrm{cms}$ at a height of $20 \mathrm{cms}$.

\section{Seating Stones}

In Nangbah capstones of various types are found in groups with dimensions of $91-152 \mathrm{cms}$ in length and 60 $152 \mathrm{cms}$ in breadth. The capstones in the village are found in association with menhirs at some places though some of these stones are found alone in several parts of the village (Figure 6).

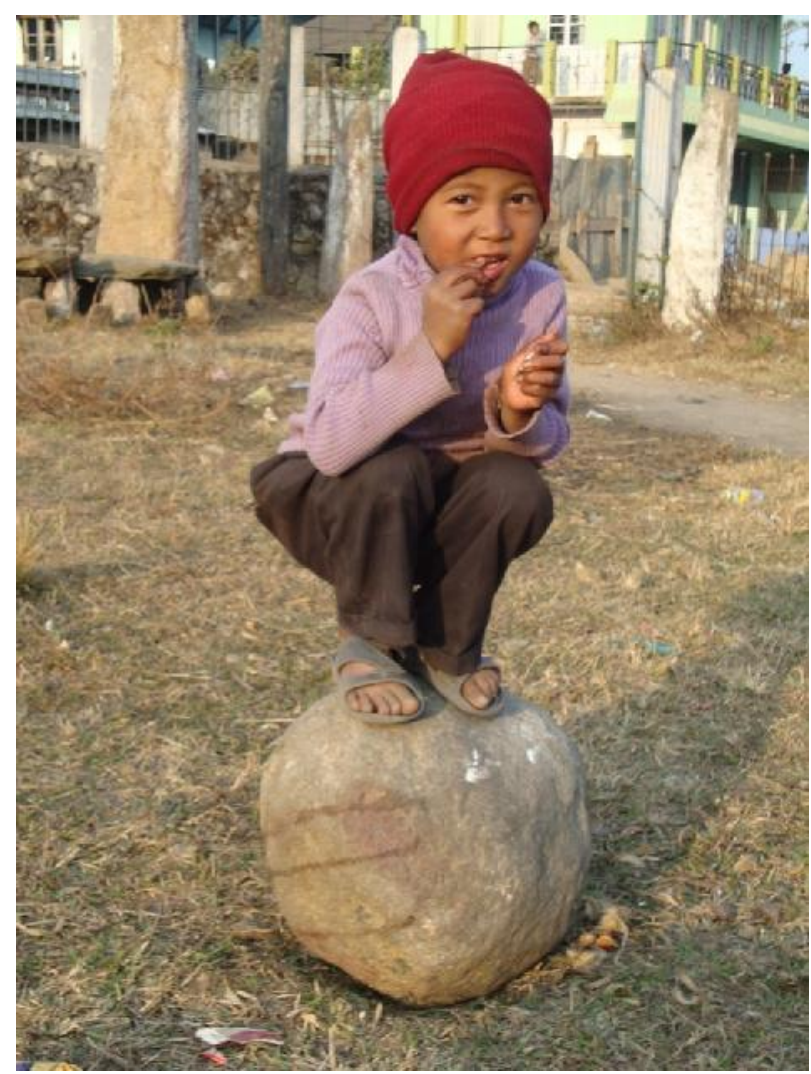

Figure 7: One of the stone mookhrah in the grove of Iawmusiang 


\section{Cists}

These are stone chambers used as a repository varying in sizes from $182 \times 213 \mathrm{cms}$ to $304 \times 365 \mathrm{cms}$. They are opened periodically by removing one of the vertical stones placed in front for depositing the ashes of the deceased ancestors. They are known as moobuhshiang (moo=stone, buh=place, shiang=bones) or moolainmotymoh (moolain refers to the vertical stone slab placed at the opening at the moobuhshiang and mootymoh refers to the capstone placed atop).

\section{Miscellaneous}

Apart from the above types, several other structures are also seen. These include ramshyllong, an oblong structure found in Iongbiam locality the size being about ten times that of a football; and mookhrah, two structures found in the grove of Iawmusiang, the size being twice that of a football with 52 and 58 inches in circumference respectively (Figure 7).

\section{B. Functional Types}

Based on their function, the megaliths of Nangbah village can be listed as below:

\section{Burial Stones}

These are directly associated with the post-cremation rituals including the disposal of remains of the deceased body. These burial chambers buried underneath, morphologically a cist, are of different sizes. The smaller ones of $182 \times 213 \mathrm{cms}$ are family burial chambers (specifically moobuhshiang), while larger ones of $304 \times 365 \mathrm{cms}$ are clan burial chambers called moobah (Figures 8 and 9). These types of burials have a vertical wall on one side which acts as a doorway (moolain).

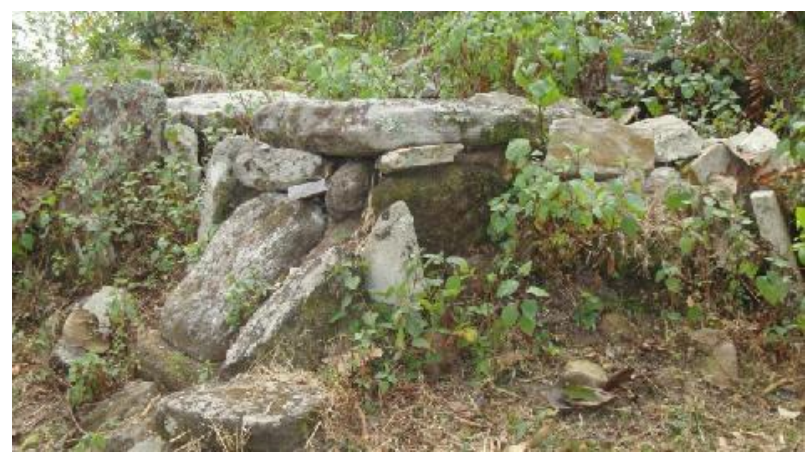

Figure 8: A family cist where ash and bones of the dead are deposited

\section{Religious Stones}

In Nangbah, touching of religious stones is considered a taboo. Some religious stones include moolyngdoh (lyngdoh stone) in Iawmusiang morphologically a dolmen. This is a sacred stone where the lyngdoh(priest) performs rituals connected to village welfare during the festivals of Pam Iawmusiang and Knia Lyngdoh. Ramshyllong is another sacred stone located in Khlopano locality at whose feet animals are sacrificed on the occasion of village festivities. Moopyllaitsyier located at Khlopano is associated with death rituals in the case of women who die during pregnancy. In such cases, a cock is allowed to scratch the menhir. The death of women during pregnancy calls for this type of ritual so as to please the souls of both the deceased mother and the child.

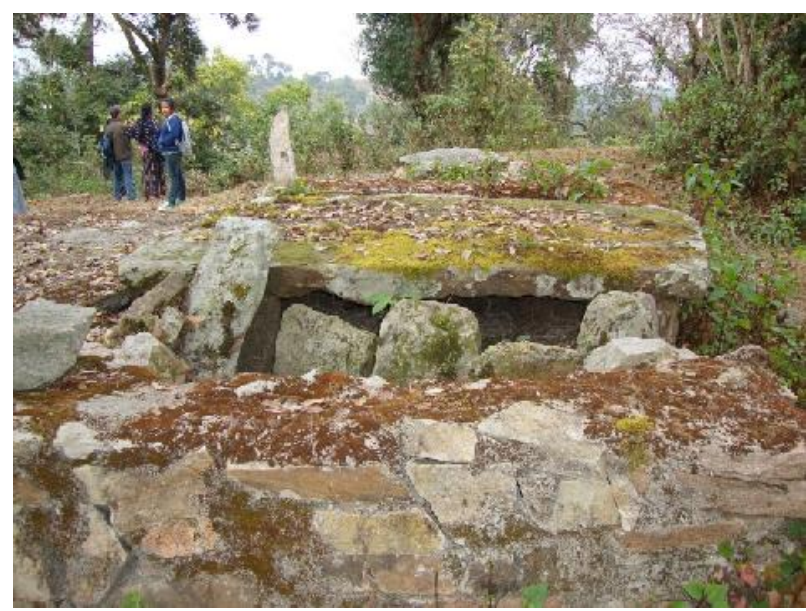

Figure 9: A clan cist where all ash and bones of all matrilineal kin are placed

\section{Memorial or Commemorative Stones}

In addition to the complex of ritualistic and funerary megalithic practices, the Jaintias build a series of stones commemorating important social and political events. Blaiiawmusiang, also known as sangap, is said to have been the first of its kind to be placed in Iawmusiang in memory of Sangap, a strong man who carried the stone from a far-away village on his head. U-moothulelane represents an important historical event that is said to have taken place. This menhir is a memorial to commemorate the bravery of Kat Treiaw who successfully defeated a "giant" who was causing tyranny. However the menhir was named after a slave who was sacrificed through deceit at the same spot (Marak and Jangkhomang 2012b).

\section{Resting Stones}

Many resting stones found in the village are meant for sitting or resting purposes. This type of stones also signifies other ceremonial functions as those in Iawmusiang. Resting stones are usually dolmen or capstone type. Sitting or resting stones can be classified both as clan sitting 
stones or sitting stones where a weary traveller takes some rest during his journey from one village to another. However these are mostly one and the same though there are some stones in several corners of the village which are set up just for sitting.

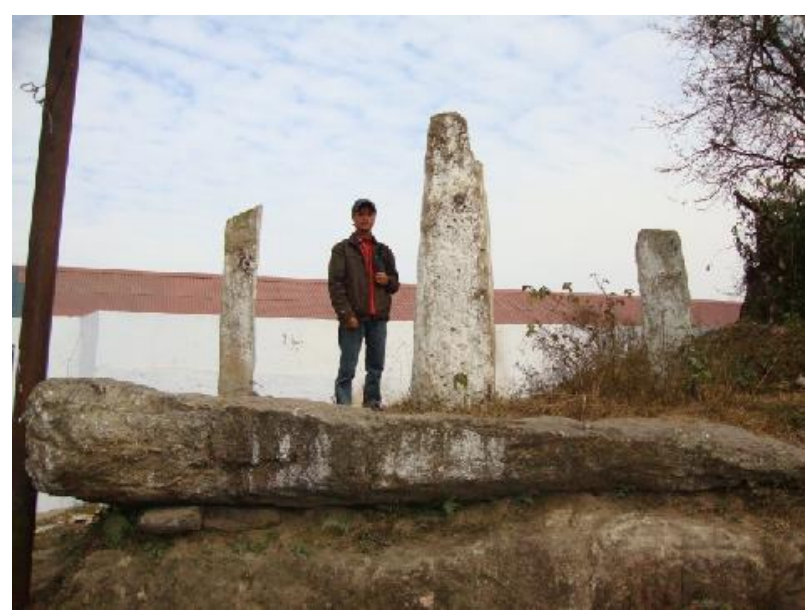

Figure 10: Khimdan, the tax collector's stone

\section{Judiciary Stones}

One of the stone found in the village having such judicial significance is the khimdan (khim=handful, dan=tax), a combination of three menhirs found in association with a flat and narrow stone (Figure 10). Nangbah, prior to British rule, was the location of one of the markets in the Jaintia kingdom. During that period, duty was imposed on every item that entered and exited the village as import and export tax. The tax collector who was in charge of this procedure collected all duties at this particular location.

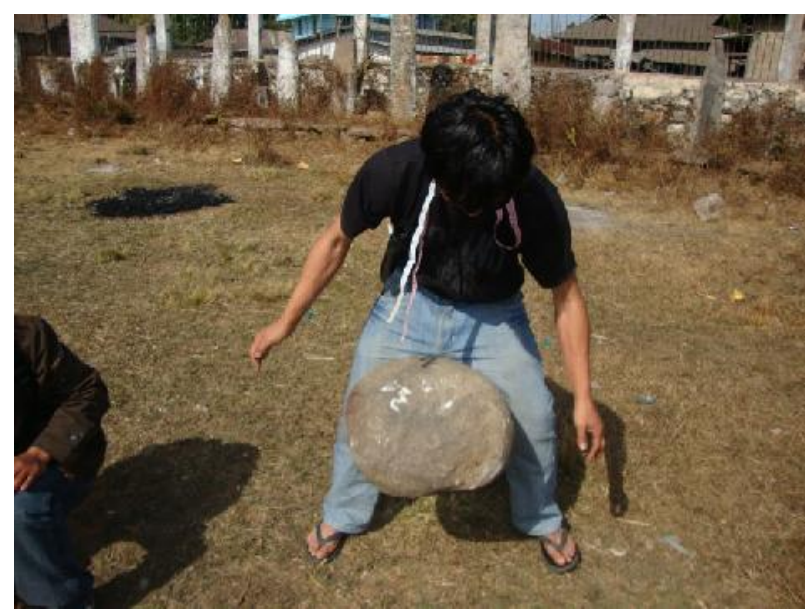

Figure 11: Stone balls used to test the strength of men

\section{Recreational Stones}

There are some megaliths found in Nangbah which have recreational values attached to them. Stone balls (mookhrah), as the name indicate, refers to stones round in shape found in Iawmusiang. These round stones symbolize the observation of a sport held annually during the Knia Lyngdoh festival before harvest. Here the stone balls are lifted and carried by young men, and the person who carries it the furthest is declared the strongest man of the village (Figure 11).

\section{CONTINUED TRADITIONS}

It is difficult to state with certainty when the megaliths in Nangbah were erected. However as many stories reveal, these were probably set up hundreds of years back. In recent times, no megalith has been built; instead some of the ones which had fallen down were re-erected and maintained, while others were renovated by cementing them with modern materials (Figure 12). Nevertheless, these structures from the past are still a part of the present day Jaintia society.

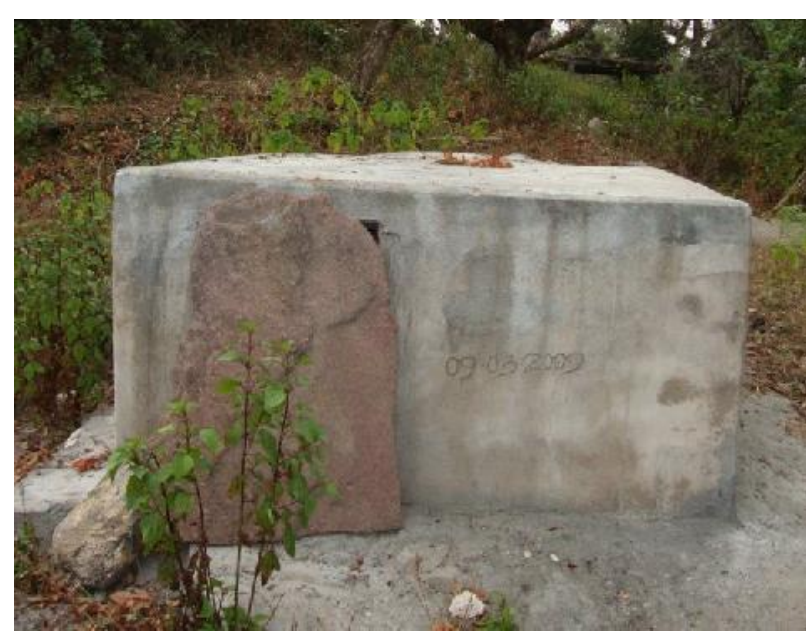

Figure 12: A cist renovated with cement and mortar

An interesting feature of Jaintia megaliths, in opposition to megaliths found in other parts of northeast India, is its funerary features. When a person dies of natural causes, his/her body is cremated. Thereafter the ashes of the deceased are collected in a piece of white cloth by the khadduh. In case there are no women in the family, this is performed by another woman from the same clan. Such collections are done using a khnap (an iron pincher). After the collection of ashes and bones, the cloth is properly wrapped and interred into the burials. In some prominent families, where a family cist exists, the ash is first deposited therein, which is later re-deposited in the clan cist. The belief in life after death is re-enforced in funeral ceremonies where the dead is given food, drink and other 
requirements on his/her journey to the after-world. In the cist, a flat stone called moosiangsangia ( $\mathrm{moo}=$ stone, siang=flat, sangia $=$ soul) is present. This is a stone "table" where foods and drinks are offered to the deceased souls. Such food items are also offered for dead ancestors, which the recently deceased soul, whose remains are being interred into the moobuhshiang, will carry and deliver.

It is thus the veneration of ancestors that stand out in Jaintia megalithic culture. If a man dies his bones are carefully kept in the individual family moobuhshiang, until they are handed over to the deceased's maternal relatives with accompanying rituals. When a woman dies her children conduct the cremation, and not her husband. A woman who dies without any children may be cremated by the husband but he cannot collect nor receive the bones which will be done by her clansmen and women. From these individual cists, the bones are collected in a year or even later and placed in a larger cist of the subclan/lineage. Thereafter after some years when the clan members are able to gather sufficient money for the ceremony, these bones from family and sub-clan cists are gathered and laid to rest in the moobah. Thus, an individual born into a clan will likely travel thrice if not twice to reach its final resting place at the clan cist, even if it takes years to do so. The above ceremonies reiterate the importance of the clan system, and therefore a person born into a clan will likely remain in it even after death.

In the village under study, besides the cists, memorials in honour of the kin are found well-maintained. These clan stones consist of three menhirs and a dolmen or five menhirs and a dolmen, sometimes the number of menhirs and dolmens going up to fifteen and ten respectively. In all cases, the central menhir is taller than those flanking it on both sides, and represents the maternal uncle of the clan. The menhirs flanking the "maternal uncle stone" represent the younger male members of a clan such as brothers and nephews. The dolmens placed in front of the menhirs are "ancestress stones". If two dolmens are placed side by side, the one to the left represent the root ancestress and the one to the right, the younger ancestress, i.e., ancestress of the sub-clan or family. These stones are annually cleaned and maintained by their respective clan members, and even a child is able to identify his/her own clan stones.

One important festival celebrated for the prosperity and well-being of the village is Pam Iawmusiang conducted inside Iawmusiang in the months of February and March. During this festival each of the twelve clans, represented by its male members, occupies its own clan stone. The lyngdoh performs rituals on the moolyngdoh dolmen to appease the goddess of Iawmusiang to protect the village from all diseases, and calamities and bestow prosperity. Sacrifice of roosters and he-goats are made to the goddess who would protect the villagers from acci- dent, theft, robbery and enhance longevity and trade. This festival is celebrated once in five years. Interestingly, before any animal sacrifice is made in the village, the first sacrifice is made at the ramshyllong menhir for the god residing therein.

In Khloo Lyngdoh grove the ritual of Knia Lyngdoh is performed annually for a good harvest, and it is again the twelve clans who congregate and pray to the spirits concerned. Every alternate year, a calf is sacrificed for which the said clans contribute. For any ceremony for the wellbeing of the village, representatives of the twelve clans are required, giving weight to local traditions that it was they who set up the village, while the other clans migrated into the village or re-grouped themselves (under a different nomenclature). In the past when the Jaintias came to occupy their present homeland, they did so in groups of clans, staking claim to the territory claimed by them (through the setting up of stones). Therefore, the clan stones, which are a memorial to the ancestors who formed the clan, can be treated as "village foundation stones", the purpose of which was to protect the village from accidents, theft and robbery, and to enhance trade and longevity (Marak and Jangkhomang 2012a). This was ordained since the spirits of the ancestors who dwell in the stones would likely bless their descendents.

\section{DISCUSSION}

The study of megalithic types and living traditions reveal several latent facets about the society. One interesting fact is the genderedness of stones that exist among the Jaintias. The common structures found in the village are menhirs and dolmens. Menhirs, interestingly, are also referred to as "male stones" while dolmens are referred to as "female stones". The difference and distinction between the two set of stones is obvious, however the concept of identifying a stone as male or female is an interesting cultural phenomenon. By nomenclature all menhirs are male stones, and all dolmens are female stones. Therefore each cluster of clan stones comprises of some male stones and some female stones. Since these clan stones represent the matrilineal kin of the clan, the male stones represent the maternal uncles and the dolmens the ancestresses. In all cases, the central menhir representing the maternal uncle is always taller than those flanking it on both sides. The dolmen placed in front of the menhirs is the ancestress stone. Gender and identity inherent in the physical attributes of the stones is an interesting feature. Masculinity entailed strength, guidance and dominance: the menhirs encompassed strength due to its size and shape; guidance since majority of the menhirs acted as path-stones and boundary-stones; and dominance since it is the tallest structure. On the other hand, femininity entailed motherhood: this is exemplified by the flat stones which structurally being opposite to the upright stones, indicate a nurturer-ancestress. This is also supported by the fact that 
the flat-stones are used as resting-stones. Furthermore, the goddess of Iawmusiang resides, not in an upright standing menhir, but in a flat-shaped dolmen (Marak and Jangkhomang 2012a).

The most interesting features of the Jaintia megaliths are its connectedness to the matrilineal system. Not only do the cists reveal matrilineal clan unity, but the memorial stones in the form of clan stones reveal much more. The latter symbolizes the matrilineal kin: those erected in honour of the founding ancestress and her kin. The tallest menhir in the cluster representing the maternal uncle has parallels in the society since he occupies the highest position in Jaintia society. He is the one who wields enormous powers in matters of the family, and the decision-maker in matters relating to the clan and the family. The menhirs next to him represent other uncles, nephews or brothers: the shortness in height representing the lower status of these male members. If there is more than one dolmen it represents the root ancestress and younger ancestresses. Depending on either size, the largest one is the stone of the root ancestress, or on orientation, the root ancestress is normally placed in front of the uncle stone, the different stones can be identified.

Besides the Jaintia social system which is highly underlined, it is seen that the megaliths are also associated with social merit. The powerful are seen to build monuments such as umoothulelane, erected by Kat Treiaw's uncle, to commemorate his victory over a cruel giant. The story of the sangap stone, equally interesting, tells how a husband had to leave his wife's house in the dead of the night in accordance to custom. It was as a mark of respect for the strength and valour of this strong man that the goddess of Iawmusiang is said to now reside herein. However megaliths among Jaintias are not set up by an individual for personal merit, rather they are set up communally to commemorate an event, an occasion, or in honour of a dead ancestor/ancestress. These structures, therefore, indicate some form of leadership and affluence which guided the people in the past. The commonness and the widespread presence of these stone structures indicate certain authoritative power or an ideology that forced them to build these structures uniformly. Possibly the emergence and establishment of syiemships, Jaintia kingdoms set up by dominant clans, were linked with megalithic activity on a larger scale. This was likely possible through the surplus generated through trade particularly in iron, lime, and other products from southern areas in the Khasi Hills, while in the Jaintia Hills through surplus generated from the control over plough agriculture of the Sylhet plains.

Christianity entered the Khasi-Jaintia Hills in the early nineteenth century and it brought a change in the sociocultural life of the people. As a result of the spread of Christianity and the missionary zeal to dispel ignorance, superstition and the worship of evil spirits that the mega- lithic tradition was seriously eroded and gradually disappeared (Mawlong 2009).However in the village under study the cultural practices are still alive. Understandably, Christian families are no longer following ancestral practices of periodical bone collection of the dead, and instead the dead are buried in accordance to Christian rituals. The diminishing interest in the traditional beliefs and practices among Christians is mirrored in the lessening of sanctity of these sacred stones. A Christian does not take part in any prayer or ritual to appease the gods and goddesses residing in various sacred spaces including stones. However half of the studied population was Niamtre believers, and therefore the importance of these lithic structures were still alive. Ritualistic behaviors towards these stones were still in practice and the deposition of the deceased's family and clan repositories were still followed. During the festivals of Pam Iawmusiang and Knia Lyngdoh when several gods and goddesses are worshipped to bring prosperity and good health to the people, the Christians abstain from all the ritualistic regalia, but they take part in the celebratory feasts and sports which take place.

\section{CONCLUSION}

Classification of artifacts into disparate types is not a simple task in archaeology. Classifying a set of artifacts having living connotations is still more difficult. However, on the basis of morphology and functionality when the megaliths of the Jiantias are studied, it revealed interesting characteristics. The megaliths found could be clubbed into types such as menhirs, dolmens, cists etc., but a culturalist approach reveals that these stones could be classified differently. For instance, there were stones that were "male" and "female", while others were "family" vis-àvis "clan" repositories.

The number of stones found in Nangbah is over five hundred and all these stones have local names indicating the rich oral tradition being passed down generations and the connected cultural meanings therein. Therefore, there are stones named the "tax collector stone", where tax was collected in the past; "stone balls", symbolic of the Jaintia fascination for male strength reiterated in the sangap stone; the "stone of thulelane" in memory of a Jaintia warrior etc. These stones are either commemorative or ceremonial in nature; while others like the "lyngdoh stone" and "the stone where the cock is set free" are religious stones where rituals are performed. The latter is a sacred stone which should not be touched except by the priest. A few years ago a barricade was built all around it to prevent children from accidentally touching it since mere contact was believed to lead to unnatural deaths.

What differentiates the Khasi-Jaintia megaliths from their northeastern counterparts is the presence of funerary stones, and the striking absence of structures raised though feasts of merit which are common among the various Naga tribes of the region. It is likely that the earli- 
est Jaintia megaliths were probably the moobuhshieng where bones of ancestors were stored, built by prominent families and dominant clans, since ancestor worship forms a very important part of their religion. The construction of these structures was probably followed by other lithics, such as the clan stones, which were for commemoration of ancestors.

However, it is the system of matriliny which is highly underlined in the Jaintia megalithic culture. The underlying feature being twofold: the veneration of the dead ancestors, and the unification of the matrilineal members of a clan. This social fact is rather strong such that a person once born into a particular clan will die and remain in that clan forever. Consequently the dead are interred in their clan repositories, and it is seen that the unity of the matrilineal kin even after death is of utmost importance. Non-funerary megaliths, such as clan stones, also has a strong connection to the matrilineal system - such that there are stones in memory of the ancestress and maternal uncles - reiterating the social position of the matrilineal kin. The position of the ancestress and the maternal uncle is underlined where women were venerated as founders of the clans, but also acted as mere custodians while men were the decision-makers. The veneration of the matrilineal clan is also restated by the presence of stones dedicated to twelve clans such as the Pasi, Lamare and others which are annually worshipped during the festival of Pam Iawmusiang for the prosperity of the respective clan members.

\section{REFERENCES}

Bezbaruah, D. 2004. Megalithic Remains in Karbi Anglong District, Assam: A Study in the Context of Karbi Culture. Unpublished PhD Dissertation, Department of Anthropology, Gauhati University, Guwahati.

Bradley, R. 1998. The Significance of Monuments: On the Shaping of Human Experience in Neolithic and Bronze Age Europe. London: Routledge.

Chapman, R. 1981. The emergence of formal disposal areas and the 'problem' of megalithic tombs in prehistoric Europe. In R. Chapman, I. Kinnes and K. Randsborg (eds.), The Archaeology of Death, pp. 71-82. Cambridge: University Press.

Devi, P. B. 2011. Megalithic Culture of Manipur. Delhi: Agam Kala Prakashan.

Dewar, S. 1966. The Ceremony of Erecting a Megalith among the Angami Nagas, Folklore 77 (4): 264-69.

Flemming, A. 1973. Tombs for the Living, Man 8(2):178-93.

Furer-Haimendorf, C. 1945. The Problem of Megalithic Cultures in Middle India, Man in India 25 (2): 73-86.

Godwin-Austen, H. H. 1872. On the Stone Monuments of Khasi Hills Tribes, Journal of the Royal Anthropological Institute 1: 122-36.

Gurdon, P. R. T. 1914. The Khasis. London: Macmillan.
Hodder, I. 1990. The Domestication of Europe: Structure and Contingency in Neolithic Societies. Oxford: Basil Blackwood.

Jamir, W. 1998. Megaliths in Nagaland, Purattatva 28: 104-10.

MacKie, E. 1997. Maeshowe and the winter solstice: ceremonial aspects of the Orkney Grooved Ware culture, Antiquity 71: 338-59.

Marak, Q. 2012. Megaliths of North East India. In T. B. Subba (ed.), North-East India: A Handbook of Anthropology, pp. 34-53. New Delhi: Orient Blackswan.

Marak, Q and Jangkhomang. 2012a. The "Sacred Stones" of Nangbah: A Post-Processual Cultural Interpretation of Megaliths. Journal of Social Sciences, Humanities and Literature 1 (2): 62-77.

Marak, Q and Jangkhomang.2012b. Megaliths, Matriliny, and Living Practices: A Study of the Jaintia Megalithic Traditions in Meghalaya. Indian Anthropologist 42 (2): 67-82.

Marak, Q and S. Ghimire. 2012. How Sacred are Khloo Blai? A Look into the Pnar Jaintia Concept of Sacred Groves. The Eastern Anthropologist 65 (3): 339-54.

Mawlong, C. A. 2009. Christianity and Megalithic Tradition in the Khasi-Jaintia Hills: A Preliminary Study of the Processes of Deculturation and Enculturation. In T. B. Subba, J. Puthenpurakal and S. J. Puykunnel (eds.), Christianity and Change in Northeast India, 194-202. New Delhi: Concept Publishing Company.

Mills, J. P and J. H. Hutton. 1929. Ancient Monoliths of North Cachar, Journal of Asiatic Society of Bengal XXV (1): 185-300.

Nelson, S. M. 1999. Megalithic monuments and the introduction of rice into Korea. In C. Gosden and J. Hather (eds.), The Prehistory of Food: Appetites for Change, pp. 147-65. New York: Routledge.

Ramachandran, K. S. 1971. Bibliography of Indian Megaliths. Madras: State Department of Archaeology.

Renfrew, A. C. 1976. Megaliths, territories and populations. In S. J. De Laet (ed.), Acculturation and Continuity in Atlantic Europe, pp. 198-220. Bruges: de Tempel.

Sen, S. 2004. Khasi-Jaintia Folklore: Context, Discourse and History.Chennai: National Support Folklore Centre.

Sherratt, A. 1990. The Genesis of Megaliths: Monumentality, Ethnicity and Social Complexity in Neolithic North-West Europe, World Archaeology 22 (2): 147-67.

Singh, O. K. 1985. A Live Megalithic Culture in Manipur. In V. N. Misra and P. Bellwood (eds.), Recent Advances in Indo-Pacific Prehistory: Proceedings of the International Symposium held at Poona, December 19-21, 1978, pp. 491-96. New Delhi: Oxford \& IBH Publishing Company.

Thom, A. 1966. Megaliths and mathematics, Antiquity 40: 12128.

Thomas, J. 1993. The hermeneutics of megalithic space. In C Tilley (ed.), Interpretative Archaeology, 73-97. Oxford Berg.

Tilley, C. 2004. The Materiality of Stone: Explanations in Landscape Phenomenology. Oxford: Berg. 